\title{
Correction to: Resolution of Persistent COVID-19 After Convalescent Plasma in a Patient with B Cell Aplasia
}

\author{
Emily McKemey ${ }^{1}$ - Adrian M. Shields ${ }^{1,2}$ (D) Sian E. Faustini ${ }^{2} \cdot$ Harriet J. Hill $^{3}$ - Aliaksandra Baranskaya ${ }^{1}$. \\ Zania Stamataki $^{3} \cdot$ Simon Gompertz $^{1} \cdot$ Alex G. Richter $^{1,2} \cdot$ Davinder Dosanjh $^{1} \cdot$ Shyam Madathil $^{1}$
}

Published online: 31 March 2021

(C) Springer Science+Business Media, LLC, part of Springer Nature 2021

\section{Correction to: Journal of Clinical Immunology https://doi.org/10.1007/s10875-021-00996-7}

The original article contained a typo found in the 5th author's family name. The correct spelling is: Dr. Aliaksandra Baranskaya.

Publisher's Note Springer Nature remains neutral with regard to jurisdictional claims in published maps and institutional affiliations.

The online version of the original article can be found at https://doi.org/ 10.1007/s10875-021-00996-7

Adrian M. Shields

a.m.shields@bham.ac.uk

1 University Hospitals Birmingham NHS Foundation Trust, Birmingham, UK

2 Clinical Immunology Service, Institute of Immunology and Immunotherapy, University of Birmingham, Birmingham, UK

3 Centre for Liver and Gastrointestinal Research, Institute of Immunology and Immunotherapy, University of Birmingham, Birmingham, UK 